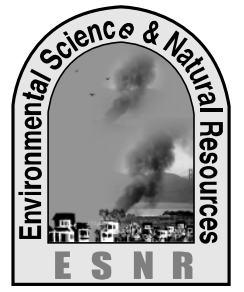

J. Environ. Sci. \& Natural Resources, 6(1): 15 - 20, 2013

ISSN 1999-7361

\title{
Housing Condition of Coastal Area in Bangladesh: A Case Study of Kutubdia, Cox's Bazaar
}

\author{
M. Mohiuddin and M. B. Latif \\ ${ }^{1}$ Department of Geography and Environment, University of Dhaka, Dhaka-1000 \\ ${ }^{2}$ Departmentof Environmental Science and Resource Management, Mawlana Bhashani Science and \\ Technology University, Santosh, Tangail-1902, Bangladesh
}

\begin{abstract}
The study attempts to show the present condition of housing and house making behavior of coastal area at Kutubdia in Cox's Bazaar District. The housing condition of Kutubdia was weak, vulnerable and faced great loss during disaster. The people of Kutubdia had no knowledge about disaster resilient housing and the financial problem also played a vital role in increasing vulnerability of housing condition. The data for the study area were collected from primary and secondary sources. The result of the study showed that $94.67 \%$ houses of coastal area Kutubdia were katcha type which was made by tin+mud, tin+bamboo, tin+wood, straw+wood and rest of houses were Pucca (1.96\%) and Semi-pucca (3.37\%). There had no remarkable change in housing structure from 1981 to 2010. Due to poverty and illiteracy, $88.96 \%$ people could not repair their houses. Loan facilities and training program on house building and disaster preparedness were very limited. As a whole, the people of coastal area (Kutubdia) were at risk to disasters.
\end{abstract}

Key Words: Housing condition, Coastal area, Kutubdia, Cox's Bazaar.

\section{Introduction}

Coastal area of Bangladesh is mainly plain low land with some offshore islands. It plays a formidable role in the economy and ecological setup of the country. In addition to vast resources, the region also considered as the country's most disaster prone area. People of that area are facing destructive cyclone, tidal surge, erosion, salinity intrusion and future threats from sea level rise and tsunami. Economically people of that area are involved primarily in fishing, salt cultivation, agriculture activities and other activities. Being a vulnerable area, the large majority of the coastal people are poor and their housing conditions are also vulnerable due to regular hit by disaster mostly cyclone at one hand and deteriorating economic condition on the other. People in Kutubdia are losing colossal lives and property from mutinous disaster. Cyclone hit these coastal areas from the historical records. It can be seen that there are two peaks (the month of April- May (pre- monsoon) and another is October- November (post-monsoon) in the annual distribution of the tropical cyclone in the Bay of Bengal. From 1891- 1990 about 700 cyclones occurred in the coastal areas (shamsujoha, 2007). In 1991 cyclone, 131000 to 139000 people died with the majority of those dying being below the age of 10 and one third of them below the age of five and the death of women outnumbered by man (Talukder and Ahmed, 1992). An estimate, about 1 million houses completely destroyed and further 1 million damaged (kausher et.al., 1996).
The housing structure is changing gradually but the structure is different from zones to zones. In the village area, the percent of Katcha houses was 82 . $32 \%$ and in urban area it was $47.67 \%$ in Bangladesh (BBS, 2001). Among the coastal districts, Cox's bazaar has more katcha houses than any other districts of Bangladesh. Cox's Bazaar Sadar and Teknaf are different from other upazila of Cox's Bazaar Districts. Housing condition in Kutubdia is a miserable one the rate of katcha houses was $95.90 \%$, semi- pucca was $2.49 \%$ and pucca was only $1.60 \%$ (BBS, 2001). The present study, therefore, focus as the housing condition of the coastal region particularly Kutubdia island and thereby to see the various problems they faced when cyclone hit the island. The specific objectives of this research were: a) to show the housing condition \& house making behavior of the people; b) to detect the changing pattern of housing of coastal area;

\section{Study Area}

The study area was confined coastal island of Kutubdia upazila in Cox's Bazaar District. The Upazila occupies an area of 2491.86 sq. $\mathrm{kms}$. It is located between $21^{\circ} 43^{\prime} \mathrm{N}$ to $21^{\circ} 56^{\prime} \mathrm{N}$ latitude and between $91^{\circ} 50^{\prime} \mathrm{E}$ to $91^{\circ} 54^{\prime} \mathrm{E}$ longitude. (BBS, 2001).The upazila is bounded to the north by Banskhali Upazila of Chittagong Zila to the east by Banskhali, Chakeria and Maheskhali on the south and to the west by the Bay of Bengal. The entire island is a very flat topology where a wide range of natural hazard are seen active such as cyclone, storm surge, tidal surge, coastal erosion, saline water intrusion etc. 


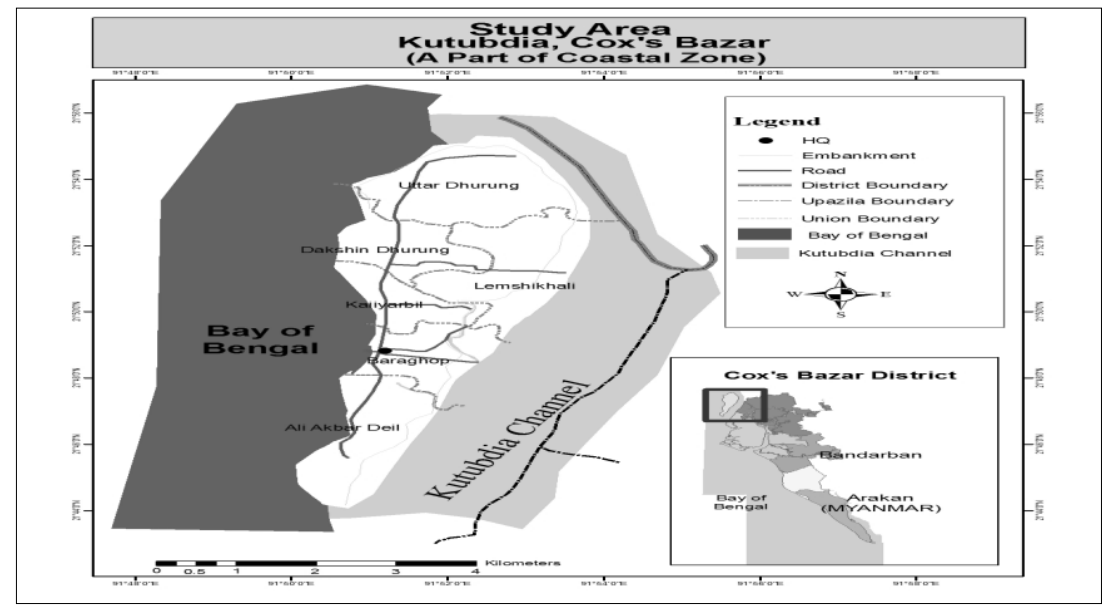

Fig 1: Location of the Study Area Kutubdia, Cox's Bazar

\section{Materials and Methods}

The study was based on primary data through pretested standardized structural questionnaire for quantitative analysis. Data were collected from randomly selected 300 households (Table 1) living at coastal area at Kutubdia in Cox's Bazaar District. Households were selected from all unions of different house structure, occupation group and income so that a complete picture of the island could be focused.

Table 1. Sample of Households by Union

\begin{tabular}{|c|c|c|}
\hline Unions & Sample Size & \\
\hline Ali Akbar Dail & 70 & \\
\hline Lamshikhali & 50 & 23.33 \\
\hline Uttaar Durang & 50 & 16.67 \\
\hline Daksin Durang & 40 & 16.67 \\
\hline Kairbill & 30 & 13.33 \\
\hline Baroghop & 60 & 10.00 \\
\hline Total & 300 & 20.00 \\
\hline
\end{tabular}

Source: Field Survey, 2010

In addition, relevant secondary information on houses from various sources such as - statistics, reports, articles and census documents etc. were also reviewed and analyzed. Secondary data were collected from various organizations like DRTMC (Disaster Research and Training Managing Center), BBS (Bangladesh Bureau of Statistics), BUET (Bangladesh University of Engineering of Technology), ISRT (Institute of Statistical Research
\& Training), and BIDS (Bangladesh Institute of Development Studies).

\section{Results and Discussions}

\section{Housing Condition of Coastal Area (Kutubdia)}

In 1981, Kutubdia had $0.65 \%$ pucca, $0.46 \%$ semi pucca houses and $98.89 \%$ katcha houses (BBS, 1981). Based on field survey 2010, the rate of pucca houses were $1.96 \%$, semi- pucca houses were $3.37 \%$ and katcha houses were $94.67 \%$ (Table 2).

Table 2. Houses Structure at Kutubdia by Time in Percent

\begin{tabular}{|c|c|c|c|c|}
\hline House Type & $\mathbf{1 9 8 1}$ & $\mathbf{1 9 9 1}$ & $\mathbf{2 0 0 1}$ & $\mathbf{2 0 1 0}$ \\
\hline Pucca & 0.65 & 1.01 & 1.60 & 3.96 \\
\hline Semi pucca & 0.46 & 1.78 & 2.50 & 3.37 \\
\hline Katcha & 98.89 & 97.21 & 95.90 & 94.67 \\
\hline
\end{tabular}

Source: BBS 1981, 1991, 2001 and Field Survey, 2010

From the Table it can be observed that the pucca and semi pucca house structure was increasing gradually but the katcha house structure was decreasing at study area from 1981to 2010.

\section{Structure of Houses}

In year 2010, 94.67\% houses were katcha in Kutubdia where as $26.84 \%$ houses were jhupri (very poor standard houses). Among the katcha houses 37.36\% 
houses which were made up with straw+mud, $6.03 \%$ houses made up with tin+bamboo, $20.79 \%$ made up with tin+mud and $37.36 \%$ made up with straw+mud remain in study area (Table 3). Only $1.96 \%$ houses were pucca type.

Table 3. The Structure of Houses of the Respondents

\begin{tabular}{|l|c|c|}
\hline \multicolumn{1}{|c|}{ Structure } & In yr 2010 (\%) & 30 yrs ago (\%) \\
\hline Pucca & 1.96 & 0.64 \\
\hline Semi- pucca & 3.37 & 0.64 \\
\hline Katcha(tin+wood) & 3.65 & 1.92 \\
\hline Katcha(tin+bamboo) & 6.03 & 9.62 \\
\hline Katcha(tin+mud) & 20.79 & 16.66 \\
\hline Katcha(straw+mud) & 37.36 & 32.38 \\
\hline Jhupri & 26.84 & 38.14 \\
\hline Total & 100.00 & 100.00 \\
\hline
\end{tabular}

Source: Field Survey, 2010

\section{Ownership Pattern of Houses}

Generally, people get their houses from father or inherited. About $81.0 \%$ people were living through generation and got ownership. But a small portion of living people $(15 \%)$ who had come from outside
Kutubdia had to buy land from others on the purpose of building houses or settlement. They were living separately from their extended family for lacking of house building area. (Figure. 2)

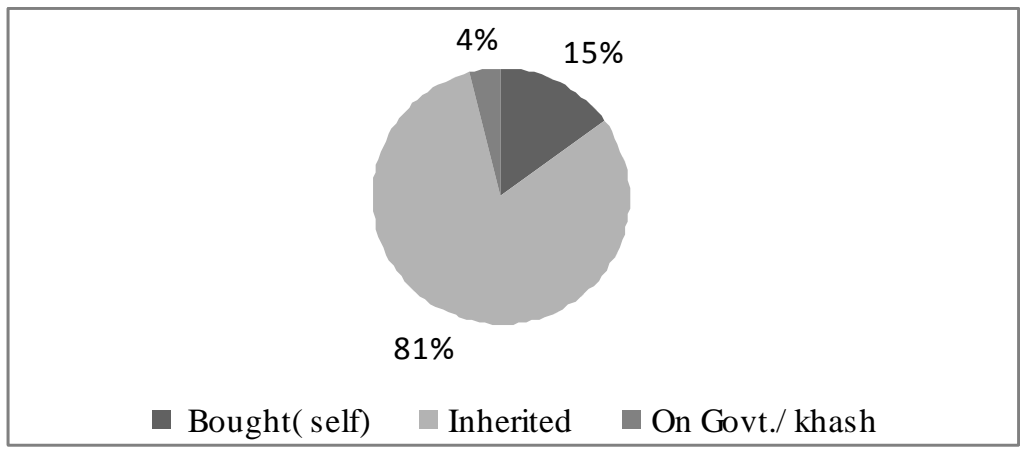

Fig 2: House Ownership Patterns

\section{Magnitude of Damages by Cyclone}

The people have affected in different time by cyclone and storm surge. On the basis of respondent's response, the memorable and mentionable cyclone and storm surge occurred in year 1991, 1996, 1997 and 2010. But the magnitudes of disasters were not same in that time.

Table 4. Damages of Houses in Taka

\begin{tabular}{|c|c|c|c|c|c|c|c|c|c|c|c|c|c|}
\hline \multirow[t]{3}{*}{ Year } & \multicolumn{10}{|c|}{ Damages of Houses (in Taka) } & \multirow{3}{*}{$\begin{array}{c}\text { Total } \\
\text { Households }\end{array}$} & \multicolumn{2}{|c|}{ Affected } \\
\hline & \multicolumn{2}{|c|}{$0-25000$} & \multicolumn{2}{|c|}{$25001-50000$} & \multicolumn{2}{|c|}{$50001-75000$} & \multicolumn{2}{|c|}{$75001-100000$} & \multicolumn{2}{|c|}{$100000+$} & & Number & Percent \\
\hline & $\mathbf{N}$ & $\mathbf{p}$ & $\mathbf{N}$ & $\mathbf{p}$ & $\mathbf{N}$ & $\mathbf{p}$ & $\mathbf{N}$ & $\mathbf{p}$ & $\mathbf{N}$ & $\mathbf{P}$ & & & $(\%)$ \\
\hline 1991 & 13 & 4.49 & 40 & 13.84 & 128 & 44.29 & 97 & 33.56 & 11 & 3.80 & 289 & 289 & 100.00 \\
\hline 1996 & 20 & 6.78 & 112 & 37.98 & 40 & 13.56 & 6 & 2.3 & - & - & 295 & 178 & 60.33 \\
\hline 1997 & 12 & 4.06 & 67 & 22.71 & 89 & 30.16 & 20 & 6.77 & 2 & 0.88 & 295 & 190 & 64.40 \\
\hline 2010 & 7 & 2.33 & 47 & 15.67 & 25 & 8.33 & - & - & - & - & 300 & 79 & 26.33 \\
\hline
\end{tabular}

Source: Field Survey, 2010

Table 4 showed that $44.29 \%$ (loss $50001-75000$ in taka) houses were damaged by disaster in year 1991 and $37.98 \%$ (loss25001-50000 in taka) were damaged by disaster in year 1996. Almost $100 \%$ and $60.33 \%$ houses were affected respectively in year 1991 and
$* \mathrm{~N}=$ number $* \mathrm{P}=$ percent

1996. In year 2010, $26.33 \%$ houses were damaged by disaster in Kutubdia.

\section{Damage of Houses by Structure and Time}

According to this study, semi pucca (1.73\%), katcha $(59.17 \%)$ and wicker $(39.10 \%)$ were affected by 
cyclone in year 1991 and in year 1997, 34.23\% katcha and $30.17 \%$ wicker houses were affected by cyclone in the study area. In year 2010, $10.66 \%$ katcha (made up with tin+bamboo and straw+mud) and $15.67 \%$ wicker houses were affected by cyclone.(Table 5)

Table 5. Cyclone Affected Houses by Structure and Time

\begin{tabular}{|c|c|c|c|c|c|c|c|c|}
\hline \multirow[t]{3}{*}{ House type } & \multicolumn{8}{|c|}{ Types of house affected by year } \\
\hline & \multicolumn{2}{|c|}{1991} & \multicolumn{2}{|c|}{1996} & \multicolumn{2}{|c|}{1997} & \multicolumn{2}{|c|}{2010} \\
\hline & $\mathbf{N}$ & $\mathbf{P}$ & $\mathbf{N}$ & $\mathbf{p}$ & $\mathbf{N}$ & $\mathbf{p}$ & $\mathbf{N}$ & $\mathbf{P}$ \\
\hline Semi-pucca & 5 & 1.73 & - & - & - & - & - & - \\
\hline Katcha(tin+bamboo) & 20 & 6.92 & 10 & 3.38 & 7 & 2.37 & 5 & 1.66 \\
\hline Katcha(tin+mud) & 25 & 8.65 & 15 & 5.08 & 17 & 5.76 & - & - \\
\hline Katcha(straw+mud) & 105 & 37.03 & 67 & 22.71 & 77 & 26.10 & 27 & 9.00 \\
\hline Total & 289 & 100.00 & 178 & 60.33 & 190 & 64.40 & 79 & 26.33 \\
\hline
\end{tabular}

Source: Field Survey, 2010

$* \mathrm{~N}=$ number $* \mathrm{P}=$ percent

\section{House Damage by Nature and Year}

As a result of cyclone in 1991, the damage of houses was extensive at Kutubdia. About 43,139 houses were damaged, where, 41,120 houses were fully and 2019 houses were partially damaged. Then 9000 families became shelter less. The remaining affected people did not get proper help in housing from any source.

Table 6. House Damaging Pattern by Time

\begin{tabular}{|c|c|c|c|c|c|c|c|c|}
\hline \multirow[t]{3}{*}{ Nature of damages } & \multicolumn{8}{|c|}{ Surveyed (HH) and time of losing houses } \\
\hline & \multicolumn{2}{|c|}{1991} & \multicolumn{2}{|c|}{1996} & \multicolumn{2}{|c|}{1997} & \multicolumn{2}{|c|}{2010} \\
\hline & $\mathbf{N}$ & $\mathbf{p}$ & $\mathbf{N}$ & $\mathbf{p}$ & $\mathbf{N}$ & $\mathbf{P}$ & $\mathbf{N}$ & $\mathbf{P}$ \\
\hline Broken down of houses & 90 & 31.14 & 45 & 15.25 & 97 & 32.88 & - & - \\
\hline Roof damage & 8 & 2.77 & 71 & 24.06 & 68 & 23.10 & - & - \\
\hline Partial damage & 2 & 0.69 & 60 & 20.33 & 15 & 4.48 & 70 & 23.33 \\
\hline
\end{tabular}

Source: Field Survey, 2010

$65.40 \%$ houses were washed out totally in 1991 but in 1996, 1997 and 2010 washed out houses were very little. But the houses were broken down for their weak structure in $1996(15.25 \%)$ and in 1997 (32.88\%) (Table 6).

\section{Source of Repairing Cost by Time}

People built and repaired their houses by their own cost before disaster and after disaster. They built their houses by own cost, Govt. and NGOs donation. In pre- disaster, $73.33 \%$ people renovated their houses
$* \mathrm{HH}-$ Household Head, $* \mathrm{~N}=$ number $* \mathrm{P}=$ percent

by their own cost and $20 \%$ took loan from NGOs. Rests of them tried to rebuild their houses by different sources. In post- disaster, $39.67 \%$ people repaired by own cost and $40.33 \%$ of the local people repaired their houses by NGOs, Govt. and Own cost (Figure 3).

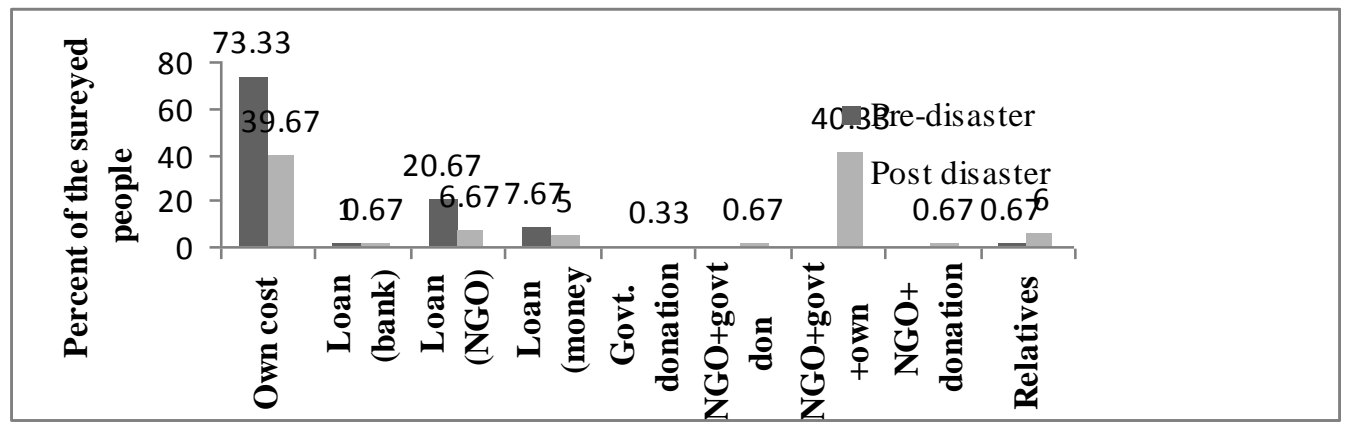

Fig 3: Sources of Repairing Cost of the House by Pre-Disaster and Post Disaster of the Respondent 


\section{House Repairing Frequency and Costs}

From the Table 7 it can be observed that total $52.67 \%$ houses were needed to be repaired in each year. Of these, repairing costs of $13.67 \%$ houses, $48.33 \%$ houses and $4 \%$ houses were respectively the range from 0-5000, 5001-10000 and 10001-15000 in study area. $10 \%$ houses were repaired after 2 years later and repairing costs for those houses was the range from (10001-15000) tk. Total $11.67 \%$ houses were repaired after 6 years later.

Table 7. House Repairing Frequency and Costs

\begin{tabular}{|c|c|c|c|c|c|c|c|c|c|c|}
\hline \multirow[t]{3}{*}{ Frequency } & \multicolumn{10}{|c|}{ Repairing cost in taka } \\
\hline & \multicolumn{2}{|c|}{$0-5000$} & \multicolumn{2}{|c|}{$5001-10000$} & \multicolumn{2}{|c|}{$10001-15000$} & \multicolumn{2}{|c|}{$15000+$} & \multicolumn{2}{|c|}{ Total } \\
\hline & $\mathbf{N}$ & p & $\mathbf{N}$ & $\mathbf{p}$ & $\mathbf{N}$ & $\mathbf{p}$ & $\mathbf{N}$ & $\mathbf{P}$ & $\mathbf{N}$ & p \\
\hline Every year & 41 & 13.67 & 120 & 48.33 & 12 & 4.00 & - & - & 158 & 52.67 \\
\hline 2 years & - & - & 35 & 11.67 & 40 & 10.00 & - & - & 75 & 25.00 \\
\hline 2-4years & - & - & - & - & 13 & 4.33 & - & - & 13 & 4.33 \\
\hline 4-6year & - & - & - & - & 2 & 0.67 & 17 & 2.31 & 19 & 6.33 \\
\hline $6+$ year & - & - & - & - & - & - & 35 & 5.00 & 35 & 11.67 \\
\hline Total & 41 & 13.67 & 155 & 51.67 & 67 & 22.33 & 52 & 17.33 & 300 & 100.00 \\
\hline
\end{tabular}

\section{The Structural Condition of Houses}

Based on field survey 2010, a significant number of respondents urged that $56 \%$ houses were vulnerable and $44 \%$ houses were not vulnerable in the study area.

\section{Causes of Not Repairing Houses}

Nevertheless, due to money $88.96 \%$ people could not repair their houses. $7.14 \%$ people could not repair their houses due to facilities (Loan facilities and training program on house building and disaster preparedness) and 2\% could not repair their house due to time. (Figure 4)

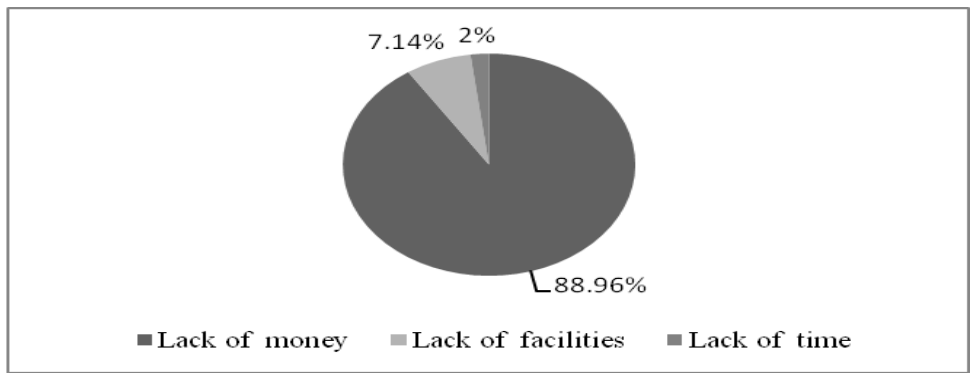

Figure 4: Causes of Not Repairing Houses

\section{Conclusion}

On the basis of the above findings it was evident that most of the houses of Kutubdia were katcha type (made up with tin+wood, tin+bamboo, tin+mud, straw+mud and jhupri) and vulnerable. Semi pucca and kutcha type houses were damaged partially or totally by cyclone in year 1991, 1996, 1997 and 2010. $88.96 \%$ people could not repair their houses where as a small portion of damaged houses were repaired by own cost, loans, NGOs and govt. donations. Based on the study on the housing condition of Kutubdia the following recommendations can be made to improve the condition of houses and disaster resilient housing: 1). National housing policy should have included disaster resilient housing and its proper development. 2). Govt. and NGOs should provide (condition free) soft loan to the people of Kutubdia for building disaster resilient housing and for repairing houses to mitigate disaster. 3). Govt. should build the multistoried pucca building (community building) that can mitigate the effect of disaster. 4). Provides the technical support for disaster resilience housing structure and arrange a program on disaster preparedness and awareness. 5). Especially, a specific sector should remain in developing coastal housing structure in every Govt. budget. 


\section{References}

BBS, 1980. Statistical yearbook of Bangladesh 1979, Bangladesh Bureau of Statistics, Ministry of Planning, Government of People's Republic of Bangladesh, Dhaka.

BBS, 1982. Statistical yearbook of Bangladesh 1981, Bangladesh Bureau of Statistics, Ministry of Planning, Government of People's Republic of Bangladesh, Dhaka.

BBS, 1984. Bangladesh population census 1981, community series of all coastal districts, Bangladesh Bureau of Statistics, Ministry of Planning, Government of People's Republic of Bangladesh, Dhaka.

BBS, 1998. Summary Report of household Expenditure survey 1996-96, Bangladesh Bureau of Statistics, Ministry of Planning, Government of People's Republic of Bangladesh, Dhaka.

BBS, 2002. Statistical yearbook of Bangladesh 2001, Bangladesh Bureau of Statistics, Ministry of Planning, Government of People's Republic of Bangladesh, Dhaka.

BBS, 1961. Population Census of East Pakistan 1961, Census Bulletin No.2, Office of the
Census Commissioner, Ministry of Home Affairs, Karachi.

Disaster Management Bureau. 1995. People Response for Flood Mitigation, Government of People's Republic of Bangladesh, Disaster Management Bureau, Dhaka.

Kausar, A. 1996. Climate change and sea level rise: The case of Bangladesh costal; In the implication of climate change and sea level change for Bangladesh (eds R.K Warrik) kluer academic, Dordrecht, 1996 (335-396p)

Ministry of housing \& Public Works. 1995 \& 1996. Parikalpita Grihayan, Housing \& Settlement Directorate, Ministry of Housing \& Public Works, Govt. of the People's Republic of Bangladesh.

Shamsuddoha, M. 2007. Climate Change impact and Disaster vulnerability in the Coastal Areas of Bangladesh. Dhaka -1207.

Talukder, J. 1992. The April Disaster: Study on cyclone- affected region in Bangladesh, Community development library. Dhaka.

Talukdar, J. and Roy, G. D. 1992. Living with Cyclone: Study on Storm Surge Prediction and Disaster Preparedness, Community Development Library, Dhaka. 